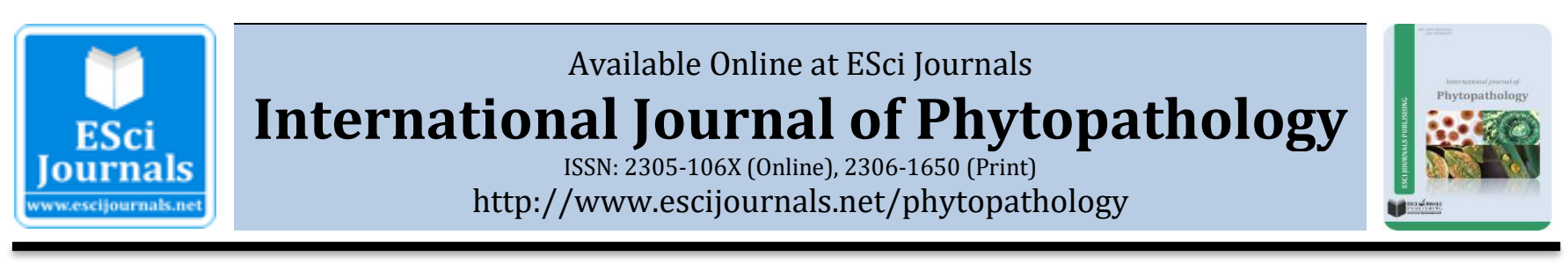

\title{
PREVALENCE AND INTENSITY OF BARLEY DISEASES IN SOUTH TIGRAY, ETHIOPIA
}

Teklay A. Teferi, Muruts L. Wubshet

TARI, Alamata Agricultural Research Centre, Alamata, Ethiopia.

\begin{abstract}
A B S T R A C T
Barley is attacked by many diseases and hence, the study was conducted to quantify and profile barley affecting diseases for management options. The survey was based on the assessment of barley fields at $5 \mathrm{~km}$ interval. Results indicated that powdery mildew, leaf rust, stem rust, leaf scald, and smuts were among the important diseases in south Tigray. The prevalence of the former diseases was 60,60, 40, 47.8, and 40\%, respectively. The incidence of powdery mildew, scaled, leaf rust and stem rust was $100 \%$ in considerable fields and cultivars. The incidence of smuts was ranged from $5 \%$ to $30 \%$. Similarly, the mean severities of powdery mildew, leaf rust, stem rust and leaf scald were $43.4,54.5,45$ and $20 \%$, respectively, while, smuts caused complete spike losses. Therefore, investigating of the pathogens variability especially for rusts, powdery mildew and scald as well as developing integrated management options for all diseases is of concern.
\end{abstract}

Keywords: Barley, Diseases, Incidence, Prevalence, Severity.

\section{INTRODUCTION}

Despite barley's long history of cultivation in Ethiopia with diverse farmers' varieties, traditional practices, and its valuable uses (Ayele et al., 2008), the production and productivity of the crop have been low $(<2 \mathrm{t} / \mathrm{ha}$ ) (CSA, 2015). This yield level is lower than worldwide and national yield potential (Lake et al., 1996; Ayele et al., 2008) obtained under well managed plots in the country (MoA, 2014). The low productivity of the crop is associated with multidimensional abiotic and biotic factors. Among the yield limiting biotic factors, diseases remain a major biotic constraint on barley production in Ethiopia.

Barley is affected by several fungal, nematode, viral and bacterial diseases. As many as 23 fungi, two bacteria, two viruses, and nine nematodes infect barley (Bekele, 1985; Semeane et al., 1996). Among which, powdery mildew (Blumeria graminis f.sp. hordei, synonym: Erysiphe graminis f.sp. hordei), leaf rust (Puccinia hordi), scald (Rhynchosporium secalis) and smuts (Ustilago hordei and U. nuda)) are serious foliar diseases that affect the crop in many major production regions of Ethiopia and it is of great economic importance (Shehabu and Tekalign, 2004; Ayele et al., 2008; Woldeab et al., 2011). Many survey

* Corresponding Author:

Email: teklayabebe6@gmail.com

(C) 2017 ESci Journals Publishing. All rights reserved. studies have been conducted in Ethiopia (Bekele, 1985; Ayele et al., 2008; Woldeab et al., 2011). However, the importance of most barley diseases in Tigray region was not well documented and profiled in recent years. Therefore, pathogen surveillance and monitoring to understand and generate information regarding the distribution or patterns is of a greater value before setting of any management strategies. Having the above scenario in view, this paper presented the prevalence and intensity of barley affecting diseases in south Tigray, Ethiopia.

\section{MATERIALS AND METHODS}

Area Description: Tigray forms the northernmost reaches of Ethiopia and is located between $36^{\circ}$ and $40^{\circ}$ east longitude and $12.15^{\circ}$ and $14^{\circ} 57^{\prime}$ north latitude. The region has six administrative zones, of which, South zone is among the major barley producing areas of the region (CSA, 2015). The survey program covered the most important barley growing districts of Ofla, Enda-Mekoni, Emba-Alaje and Raya-Alamata in South Tigray (Table 1).

Disease assessment: Barley disease survey was conducted in four districts of South Tigray in 2015 main cropping season. The survey trips were made using the main roads and accessible routes in each survey district, and in each available barley field at $5 \mathrm{~km}$ stops intervals based on vehicle odometers. At least five stops were made in each barley field depending on the farm size. 
Table 1. Coordinates and climatic conditions of the districts in the survey year in South Tigray.

\begin{tabular}{lccccc}
\hline \multirow{2}{*}{ Districts } & \multirow{2}{*}{$\begin{array}{c}\text { Altitude range } \\
(\mathrm{m})\end{array}$} & \multicolumn{2}{c}{ Coordinates (range) } & \multicolumn{2}{c}{ Weather condition (range) } \\
\cline { 2 - 5 } & $1494-2512$ & $12^{\circ} 21^{\prime}-12^{\circ} 23^{\prime}$ & $039^{\circ} 20^{\prime}-039^{\circ} 34^{\prime}$ & $400-700$ & $16-27$ \\
\hline Raya-Alamata & $1902-2764$ & $12^{\circ} 52^{\prime}-12^{\circ} 59^{\prime}$ & $039^{\circ} 26^{\prime}-039^{\circ} 33^{\prime}$ & $600-900$ & $9-20$ \\
Emba-Alaje & $2288-2977$ & $12^{\circ} 44^{\prime}-12^{\circ} 49^{\prime}$ & $039^{\circ} 31^{\prime}-039^{\circ} 32^{\prime}$ & $600-800$ & $12-22$ \\
Enda-Mekoni & $1848-2727$ & $12^{\circ} 29^{\prime}-12^{\circ} 39^{\prime}$ & $039^{\circ} 16^{\prime}-039^{\circ} 42^{\prime}$ & $700-800$ & $10-22$ \\
Ofla & & &
\end{tabular}

The prevalence of the diseases was computed using the number of fields affected divided by a total number of fields assessed and expressed as a percentage. The incidence of barley diseases was determined from the ratio of a number of infected plants to the total plants assessed and expressed in percentage.

Powdery mildew severity was recorded on a scale of 0-9, corresponding to 0 : free of disease, 1: a few isolated lesions on only the lowest leaves, 3 : light infections on the lower third of the plant with the lower most leaves infected at moderate to severe levels, 5: severe infection on lower leaves with light to moderate infection on the middle leaves, 7: severe infections on both lower and middle leaves with some infection on the flag leaf as well, and 9: severe infection on all leaves with spikes infected as well (Bennett and Westcott, 1982; Sheng and Duan, 1991). An assessment of leaf scald severity was recorded on a scale of 0-9 (Couture, 1980), corresponding to free of disease (0: no visible infection on leaves) to highly susceptible (9: all leaves of the plant severely affected). Plant response for leaf rust was expressed in five infection types according to Johnston and Browder, (1966) i.e. Immune (0), no uredia or other macroscopic sign of infection, Resistant (R), small uredia surrounded by necrosis, Moderately Resistant (MR), small to medium uredia surrounded by chlorosis or necrosis, Moderately Susceptible (MS), medium-sized uredia that may be associated with chlorosis and Susceptible (S), large uredia without chlorosis or necrosis. Leaf rust severity was expressed as percentage coverage of leaves with rust pustules following Cobb's scale modified by Peterson et al., (1948). Similarly, stem rust infection type and severity was based on the Roelfs et al., (1992) and Peterson et al., (1948), respectively.

The average disease index (DI) for each field was calculated as:

DI (\%) $=\frac{\sum(\text { disease grade } \mathrm{x} \text { number of plants in each grade })}{\sum(\text { disease grade } \mathrm{x} \text { number of plants in each grade })} \times 100$

The severity of smuts was estimated using its incidence as all infected spikes or kernels was caused complete yield loss.

\section{RESULTS AND DISCUSSION}

The survey results from the four districts are illustrated in Table 2 and 3. The result of field survey in major barley growing areas indicated that the distribution and severity levels of each disease vary within and among districts (Table 2 and 3). During the season, five barley diseases: powdery mildew, leaf rust, stem rust, leaf scald and smuts all affected barley. The pathogen populations of leaf rust, scald, and powdery mildew on barley were reported in Ethiopia by Stewart and Yirgu, (1967). Of the 70 fields surveyed, the mean prevalence of powdery mildew was $60 \%$. The prevalence of powdery mildew was dominant in Ofla, Enda-Mekoni and Raya-Alamata districts with values of $70 \%$ and more. The prevalence of the disease was not more than 11\% in Emba-Alaje district. This revealed that the importance of the disease in all barley growing areas of south Tigray was a major challenge curtailing its productivity. The incidence of powdery mildew was reached as high as $100 \%$ in Ofla, Enda-Mekoni and RayaAlamata districts and 50\% in Emba-Alaje district. The mean incidence of the disease was above $50 \%$ in the former two districts followed by $36 \%$ in Raya-Alamata and 5\% in Emba-Alaje district. The severity of powdery mildew was higher in Enda-Mekoni district ranged from 5\% to $100 \%$ followed by Ofla district with severity values of $5 \%$ to $80 \%$. The mean severity of the disease in Raya-Alamata, Emba-Alaje, Ofla and Enda-Mekoni districts was 10, 25, 40 and $52.6 \%$, respectively (Table 2 ). This study revealed that powdery mildew was among the important and widely distributed diseases of barley in south Tigray. This is by far disagreed with previous reports that it was categorized as a miner disease in Ethiopia (Ayele et al., 2008). This could be due to the fact that the divergence in climatic condition, level of resistance in cultivar as well as pathogen variability or pathotypes.

Smut (loose and head/covered) diseases were among the important diseases during 2015 main cropping season in south Tigray. During the season, smuts were found in the majority of barley fields especially those fields covered by local cultivars with an overall prevalence of $60 \%$. The 
higher prevalence and incidence of smuts in local cultivars is associated with the use of farmers' saved uncertified and untreated seeds (personal communication). The prevalence of smut in Raya-Alamata, Emda-Mekoni, Ofla and Emba-Alaje was 80, 69.6, 60.9, and 43.5\%, respectively. The severity of loose and head smut is explained by its incidence due to the fact that infected spike or kernel caused total yield loss. Hence, the incidence of the disease was ranged from free of disease to $30 \%$ and with a mean value of below $5 \%$. This survey results are in line with the report of Ayele et al., (2008) that stated smuts were among the important diseases in Ethiopia in general and Tigray region specifically.

Barley leaf scald was found important in all the surveyed areas in 2015 cropping season. The prevalence of scaled was varied from $36.8 \%$ to $60 \%$. The incidence of leaf scald reached as high as $100 \%$ in Ofla, Enda-Mekoni and EmbaAlaje districts with mean incidence ranged from $16.1 \%$ to $22.6 \%$. The incidence of leaf scald in Raya-Alamata varied from free of disease to as high as $50 \%$. Similarly, the severity of the disease was also higher in the former three districts (Table 2). The mean severity of leaf scald was relatively high in Emba-Alaje district other than the remaining three districts.

Table 2. Prevalence and intensity of powdery mildew, smuts and leaf scald on barley in south Tigray during 2015 main cropping season.

\begin{tabular}{|c|c|c|c|c|c|}
\hline \multirow{2}{*}{ District } & \multirow{2}{*}{\multicolumn{2}{|c|}{ Parameter }} & \multicolumn{3}{|c|}{ Diseases } \\
\hline & & & Powdery mildew & Smuts & Leaf scald \\
\hline \multirow[t]{6}{*}{ Ofla } & Surveyed fields & & 23 & & \\
\hline & Prevalence (\%) & & 74 & 60.9 & 39.1 \\
\hline & Incidence (\%) & Range & $0-100$ & $0-30$ & $0-100$ \\
\hline & & Mean & 52.6 & 5.7 & 22.6 \\
\hline & Severity (\%) & Range & $5-80$ & 100 & $5-30$ \\
\hline & & Mean & 40 & 100 & 17.8 \\
\hline \multirow[t]{6}{*}{ Emba-Alaje } & Surveyed fields & & 19 & & \\
\hline & Prevalence (\%) & & 10.5 & 43.5 & 36.8 \\
\hline & Incidence (\%) & Range & $0-50$ & $0-15$ & $0-100$ \\
\hline & & Mean & 3.2 & 2.9 & 16.1 \\
\hline & Severity (\%) & Range & $25-30$ & 100 & $5-50$ \\
\hline & & Mean & 25 & 100 & 31.4 \\
\hline \multirow[t]{6}{*}{ Emda-Mekoni } & Surveyed fields & & 23 & & \\
\hline & Prevalence (\%) & & 82.6 & 69.6 & 43.5 \\
\hline & Incidence (\%) & Range & $0-100$ & $0-20$ & $0-100$ \\
\hline & & Mean & 52.6 & 4.6 & 18.7 \\
\hline & Severity (\%) & Range & $5-100$ & 100 & $5-50$ \\
\hline & & Mean & 52.6 & 100 & 17 \\
\hline \multirow[t]{6}{*}{ Raya-Alamata } & Surveyed fields & & & 5 & \\
\hline & Prevalence (\%) & & 80 & 80 & 60 \\
\hline & Incidence (\%) & Range & $0-100$ & $0-5$ & $0-50$ \\
\hline & & Mean & 36 & 4 & 13.3 \\
\hline & Severity (\%) & Range & $10-50$ & 100 & $5-10$ \\
\hline & & Mean & 10 & 100 & 8.3 \\
\hline \multirow[t]{6}{*}{ Grand total } & Surveyed fields & & 70 & & \\
\hline & Prevalence (\%) & & 60 & 60 & 40 \\
\hline & Incidence (\%) & Range & $0-100$ & $0-30$ & $0-100$ \\
\hline & & Mean & 45.6 & 4.6 & 18.9 \\
\hline & Severity (\%) & Range & $0-100$ & 100 & $5-50$ \\
\hline & & Mean & 43.4 & 100 & 20 \\
\hline
\end{tabular}


The severity of the disease in Ofla and Enda-Mekoni districts was almost similar probability correlated to similar weather conditions. Hundie et al. (2011) reported that leaf scald is among the important diseases that limit the productivity of barley in Ethiopia. Similarly, incidence of barley leaf scald was high in areas of $2000 \mathrm{~m}$ from sea level and above where it constituted the major barley growing areas of Tigray (MRC, 2002).

Leaf rust and stem rust were among the important diseases in Ofla district during 2015 cropping season (Table 3). Both diseases epidemically appeared in this particular district while absent in the other districts. The distribution or prevalence of leaf rust and stem rust were $47.8 \%$ and $40 \%$, respectively. The incidence of both diseases reached as high as $100 \%$ in many fields of the district with a mean incidence of leaf rust (35.2\%) and stem rust (30\%).

The seriousness of these diseases was explained by the severity they exhibited. The severities of both diseases were reached $100 \%$ with host response of moderately susceptible to highly susceptible in the district (Table 3). The elevation of the rusts affected area was ranged from 2490 to $2500 \mathrm{~m}$. This slightly differs from the earlier report that stated the intensity of leaf and stem rusts were reduced as altitude increased above $2400 \mathrm{~m}$ (Woldeab and Negash, 2001; Ayele et al., 2008). This divergence could be due to climate change caused warming of the environment suitable for the development of rust diseases. Leaf rust was among the widely distributed and cause significant yield loss in Ethiopia (Ayele et al., 2008; Woldeab et al., 2011). Leaf rust is also an important disease in all barley-growing areas of Tigray (Ayele et al., 2008).

This study also revealed that the importance of leaf rust in south Tigray regardless of its distribution. However, stem rust was not an important disease of barley in Tigray in earlier years. However, during 2015 cropping season, stem rust occurred catastrophically in major wheat and barley growing potentials of Ofla district. This is mainly associated with the availability of pathotypes that break previously resistant cultivars (Woldeab and Negash, 2001; Woldeab et al., 2011), the presence of initial inoculums coupled with the suitable climatic condition for disease development during the season and the susceptibility of barley cultivars. The race analysis of stem rust populations collected from wheat and barley revealed that all samples were attacked by the race TKTTF.

Table 3. Prevalence and intensity of barley rusts in Ofla district of south Tigray during 2015 cropping season.

\begin{tabular}{|c|c|c|c|c|c|}
\hline \multirow{2}{*}{ Diseases } & \multirow{2}{*}{ Prevalence (\%) } & \multicolumn{2}{|c|}{ Incidence (\%) } & \multicolumn{2}{|c|}{ Severity (\%) } \\
\hline & & Range & Mean & Range & Mean \\
\hline Leaf rust & 47.8 & $0-100$ & 35.2 & $5-100$ & 54.5 MRS \\
\hline Stem rust & 39.1 & $0-100$ & 30 & $10-100$ & 45 MSS \\
\hline
\end{tabular}

\section{CONCLUSION}

Barley production is suffered from different fungal diseases mainly powdery mildew, leaf scald, rusts and smuts. The complexes of these diseases together could cause significant yield losses. Therefore, regular monitoring of their intensity and virulence spectrum could play critical in the development of integrated diseases management strategies. Furthermore, development of different management options such as resistant varieties could be the best alternative solution for smallholder farmers.

\section{ACKNOWLEDGMENTS}

We would like to offer great thanks to staffs of Alamata Agricultural Research Center (AARC) of Tigray Agricultural Research Institute (TARI) for their valuable encouragement and support during the period of the study. Our gratitude also extended to Mr. Asmamaw Ali for its safe driving during the survey.

\section{REFERENCES}

Ayele, B., B. Eshetu, B. Betelehem., H. Bekele., D. Melaku., T. Asnakech., A. Melkamu., A. Amare., M. Kiros. and A. Fekede. 2008. Review of two decades of research on diseases of small cereal crops. In: Abrham, T. (eds.) Increasing crop production through improved plant protection volume $\mathrm{I}$. Proceedings of 14th annual conference of plant protection society of Ethiopia (PPSE) 19-22 Dec. 2006 Addis Ababa., Ethiopia, 375-416.

Bekele, E. 1985. A review of research on disease of barley, tef and wheat in Ethiopia. In: Abate T, (ed.). Proceedings of the review of crop protection research in Ethiopia, Institute of Agricultural Research, 4-7 Feb 1985. Institute of Agricultural Research, Addis Ababa, Ethiopia, 79-108.

Bennett, F. G. A. and B. Westcott. 1982. Field assessment of resistance to powdery mildew in mature wheat 
plants. Plant Pathol. 31: 261-268.

Couture, L. 1980. Assessment of severity of foliage diseases in cooperative evaluation tests. Can. Plant Dis. Surv. 6033-10.

Central Statistical Agency (CSA). 2015. Report on area and production of major crops (private peasant holdings, summer season of 2014/2015). Vol. I. Statistical bulletin 578, pp10-14.

Hundie, B., K. Meles., F. Abebe., A. Tekalign., M. Ayalew., G. Woldeab., Y. Worku., E. Belete. and B. Bekele. 2011. Achievements in Barley Scald research in Ethiopia. In: Mulatu, B. and S. Grando. (eds). In: barley Research and Development in Ethiopia. Proceedings of the 2nd National Barley Research and Development Review Workshop.28-30 November 2006, HARC, Holleta, Ethiopia. ICARDA, 391.

Johnston, C.O. and L.E. Browder. 1966. Seventh revision of the international register of physiologic races of Puccinia recondita f. sp. tritici. Plant Dis. Rep. 50: 756-760.

Lake, B., H. Gebre. and F. Alemayehu. 1996. Barley production and research. In: Gebre, H. and J. Van Leur. (eds.). Barley Research in Ethiopia: Past Work and Future Prospects. Proceedings of the first Barley Research Review Workshop, 16-19 0ct 1993. IAR/ICARDA, Addis Ababa, Ethiopia, 1-8.

MoA (Ministry of Agriculture) 2014.Animal and plant health regulation directorate. Crop variety register. Issue No. 17. Addis Ababa, Ethiopia.

MRC. 2002. Crop Protection Division Progress Report for the Period 1995-2002.

Peterson, R.F., A.B. Campbell. and A.E. Hannah. 1948. A diagrammatic scale for estimating rust intensity on leaves and stems of cereals. Can. J. Res. 60: 496-500.
Roelfs, A. P., R. P. Singh. and E. E. Saari. 1992. Rust Diseases of Wheat: Concept and Methods of Disease Management. Mexico, D.F: CIMMYT. pp 81.

Semeane, Y., B. Hundie., G. Woldeab. And D. Tadesse. 1996. Disease surveys and loss assessment studies on barley. In: Gebre, H. and J.A.G. van Leur (eds.). Barley Research in Ethiopia: Past Work and Future Prospects. Proceedings of the 1st Barley Research Review Workshop, 16-19 Oct 1993, Addis Ababa. IAR/ICARDA, Addis Ababa, Ethiopia, 105-115.

Shehabu, A. and A. Tekalign 2004. Yield loss due to scald and net blotch on barley in North Shewa. Pest Manag. J. Ethiopia, 8: 111-118.

Sheng, B.Q. and X.Y. Duan. 1991. Improvement of scale 0-9 method for scoring adult plant resistance to powdery mildew of wheat. Beijing Agric. Sci. 9: 38-39.

Stewart, R.B. and D. Yirgu. 1967. Index of plant diseases in Ethiopia. College of Agriculture, Haile Selassie University, Experimental Station Bulletin, 30: 1-67.

Woldeab, G., C. Fininsa., H. Singh. and J. Yuen. 2006. Virulence spectrum of Puccinia hordei in barley production systems in Ethiopia. Plant Pathol. 55: 351-357.

Woldeab, G., B. Hundie., F. Abebe., A. Tekalign., M. Degefa., K. Taddese., E. Belete. and B. Bekele. 2011. Achievements of research on Barley Rusts and Powdery Mildew in Ethiopia. In: Mulatu, B. and S. Grando. (eds). Barley Research and Development in Ethiopia. Proceedings of the 2nd National Barley Research and Development Review Workshop.2830 Nov 2006, HARC, Holetta, Ethiopia. ICARDA, PO Box 5466, Aleppo, Syria. pp xiv + 391 .

Woldeab, G. and T. Negash. Identification of slow rusting resistance to Puccinia hordei Otth. in barley. Progress Report of Plant Protection Research Centre, 1999/2001. 